\title{
Self-cleaning and Antibacterial Properties of ZnO Nanoparticles on Cotton Fabric Treated with Maleic Acid
}

\author{
Shirin NOURBAKHSH* \\ Textile Department, Islamic Azad University, Yadegare Imam Khomeini (RAH) shahre Rey Branch, Tehran, Iran \\ crossref http://dx.doi.org/10.5755/j02.ms.24745
}

Received 02 December 2019; accepted 23 January 2020

\begin{abstract}
Bi-functional finishes of cotton such as wrinkle resistance with antibacterial and self-cleaning are important in textile industry. In this case, reducing cost and duration of processing is essential. For this purpose, cotton fabric was treated with different concentrations of maleic acid (MA), sodium hypophosphite $\left(\mathrm{NaH}_{2} \mathrm{PO}_{2}\right)$ and $\mathrm{ZnO}$ nanoparticles in two methods of separately and simultaneously. Crease recovery angle and weight gain tests were examined. For measuring carboxylic acid groups of maleic acid treated cotton fabrics, methylene blue dye was used, and then, reflective spectrophotometer was used to determine methylene blue dye absorption. Self-cleaning and antibacterial properties of $\mathrm{ZnO}$ nanoparticles treated cotton fabric were investigated. For measuring zinc amount, atomic absorption analysis was applied. As the Maleic acid concentration increased, weight gain, crease recovery angle and color yield increased. Color difference or self-cleaning effect of treated fabrics showed that by increasing maleic acid concentration, color difference increased in separate method. In simultaneous treatment, by increasing MA concentration and cross-linked sites, there was a slight increase in $\Delta \mathrm{E}$ and self-cleaning effect. Results indicated that $\mathrm{ZnO}$ nanoparticles amount in separate method of treatment increased as compared with simultaneous method. Antibacterial performance decreased for simultaneous method of $\mathrm{ZnO}$ nanoparticles treatment.

Keywords: self-cleaning, antibacterial, cotton, wrinkle resistant, maleic acid, separate method.
\end{abstract}

\section{INTRODUCTION}

Polycarboxylic acids such as BTCA and Citric acid (CA) are non-formaldehyde durable press and crease resistant finishes for cotton fabrics. Maleic acid, succinic acid and tartaric acids are bifunctional carboxylic acids. Maleic acid (MA) in the presence of $\mathrm{NaH}_{2} \mathrm{PO}_{2}$ is used for wrinkle free or crease resistant of cotton fabric. By treating cotton and MA, esterification of MA happens which causes single ester linkage with cellulose. By increasing the temperature of curing, the cotton fabric treated with MA and sodium hypophosphite shows higher crease resistance, that forms cross-link of cellulose [1-3]. Yang showed that bi-functional acids and polycarboxylic acids had similar flame retardant properties. CA or BTCA treated cotton fabric indicated increase of cross-linking, stiffness, dimensional stability and crease resistance. [4-7]. Maleic acid (MA) at the present of $\mathrm{NaH}_{2} \mathrm{PO}_{2}$ reacts with cellulose to form cellulose-ester linkage, crease resistance and fire performance without change in fabric properties [2, 8, 9].

Zinc oxide is widely used in sun-screens, UV absorbers, anti-reflection coatings, photo-catalysis and catalyst [10-13]. ZnO particles are used in polymers, fabrics and cosmetic materials for UV blocking properties. This property of zinc oxide is produced when it has a nanosize. The band-gap around $3.37 \mathrm{eV}$ belong to $\mathrm{ZnO}$ and $\mathrm{ZnO}$ can absorb light around $376 \mathrm{~nm}$. Range of ultra violet light occurs at $376 \mathrm{~nm}$ and zinc oxide can absorb this light [14-16]. Because of this photo-catalytic property, zinc oxide acts as antimicrobial and self-cleaning agents under UV light [17-19]. The metal oxides like $\mathrm{CaO}, \mathrm{MgO}$ and

\footnotetext{
* Corresponding author. Tel.: +98-21-55229201; fax: +98-21-55229202.

E-mail address: nourbakhsh.sh@gmail.com (S. Nourbakhsh)
}

$\mathrm{ZnO}$ have antibacterial activity due to the formation of reactive oxygen species on the surface of metal oxides $[17,20]$. Abdelhady synthesized chitosan/ZnO nanoparticles and loaded it on cotton fabric to achieve antibacterial performance and UV blocking. Improvement in UV protection and antibacterial properties were obtained by increase of $\mathrm{ZnO} /$ chitosan concentrations [21]. Zinc oxide-soluble starch nanocomposites (nano- $\mathrm{ZnO}$ ) synthesized using water as a solvent and soluble starch as a stabilizer and coated on paper. By the treatment, antibacterial, surface strength and smoothness of paper were enhanced [11]. Self-cleaning and antibacterial properties of $\mathrm{ZnO}$ treated textiles were investigated in previous works [22-26].

In this research, cotton fabric was treated with $\mathrm{ZnO}$ nanoparticles and Maleic acid (MA) for self-cleaning effect and crease resistance. For this purpose the cotton fabric was coated with maleic acid, and then was treated using $\mathrm{ZnO}$ nanoparticles (separate method). In the second method, cotton fabric was treated with maleic acid and zinc oxide nanoparticles simultaneously.

\section{EXPERIMENTAL}

\subsection{Materials}

The used fabric in this study was a plain woven cotton fabric with weight of $143.3 \mathrm{~g} / \mathrm{m}^{2}$. The chemical used was $\mathrm{ZnO}$ nanoparticles colloidal solution with average size between 10 to $35(\mathrm{~nm})$ from Sigma Aldrich (Germany), Maleic acid and sodium hypophosphite from Merck (Germany).Methylene blue dye and nitric acid from (Applichem., Germany) were applied in this research. 


\subsection{Methods}

Cotton fabrics were treated in two methods of separate and simultaneous. In a separate method, the cotton fabric was coated using maleic acid at concentrations of $\% 2$ to 6 (\% owf) with $\mathrm{NaH}_{2} \mathrm{PO}_{2}$ (\% 1 to 3 ) at $60{ }^{\circ} \mathrm{C}$ for 30 minutes. Then they were dried at temperature of $100{ }^{\circ} \mathrm{C}$, cured at temperature of $180{ }^{\circ} \mathrm{C}$ for 2 minutes. Then treated fabrics were loaded with zinc oxide nanoparticles at concentration of $\% 0.1$ (\% owf) and temperature of $60{ }^{\circ} \mathrm{C}$ for 30 minutes, and cured at temperature of $180{ }^{\circ} \mathrm{C}$ for 2 minutes. In the simultaneous method, the $\mathrm{ZnO}$ nanoparticles and maleic acid were loaded at the same time with the same amount as much as separate method were applied at temperature of $60{ }^{\circ} \mathrm{C}$ for 30 minutes, then cured at temperature of $180{ }^{\circ} \mathrm{C}$ for 2 minutes.

For determining the carboxylic acid groups, fabrics were immersed in \% 0.1 solution of methylene blue. After 30 minutes the samples were dried at ambient temperature. $\mathrm{K} / \mathrm{S}$ value of methylene blue stained fabrics were measured by reflectance spectrophotometer(X-rite 7000A) according to AATCC standard EP6 at reflectance of $482 \mathrm{~nm}$ [27].

The weight of fabrics was obtained before $\left(W_{1}\right)$ and after $\left(W_{2}\right) \mathrm{ZnO}$ nanoparticles and MA treatment of cotton fabric according to AATCC D3776 method [28]. Weight change $(\Delta \mathrm{W})$ was measured according to the Eq. 1:

$\Delta W(\%)=\frac{W 2-W 1}{W 1} \times 100$.

Crease recovery angles of treated fabric were determined using AATCC standard test method 66. The sum of the crease recovery angles of the warp and weft (fill) were measured.

AATCC-100 standard method was used for antibacterial performance [29]. The test was carried out with two bacteria: Escherichia coli, and staphylococcus aureus. Colonies were counted after 24 hours and bacteria reduction was measured from the Eq. 2:

Bacteria reduction $(\%)=(C-A / C) \times 100$,

where $C$ is the counted colonies of cotton fabric and $A$ is the counted colonies of $\mathrm{ZnO}$ nanoparticles coated cotton fabric.

Atomic absorption spectroscopy was used for determining zinc ion amount. The cotton fabrics treated with $\mathrm{ZnO}$ nanoparticles were placed in furnace (Naberthern, Germany) at temperature of $600{ }^{\circ} \mathrm{C}$ for 3 hour, and then a solution prepared for analysis. The zinc ions content were reported in terms of grams per 100 grams of fabric.

Self-cleaning properties of $\mathrm{ZnO}$ nanoparticles treated fabrics were determined by staining methylene blue dye (\% 0.01) on treated fabrics. After drying the samples, the stained fabrics were exposed to sun light for 30 and 60 hours, and color difference of fabrics were measured before and after exposing to light using X-rite 7000A reflectance spectrophotometer. The color difference was measured according to the Eq. 3 and according to AATCC standard EP7 [30]. Where $L^{*}$ is lightness, and $a^{*}$ and $b^{*}$ are indicators of red-green and yellow-blue colors, respectively.

$\Delta \mathrm{E}=\sqrt{\Delta a^{* 2}+\Delta b^{* 2}+\Delta L^{* 2}}$.
FTIR/ATR Bruker Tensor 27 was used for infrared spectra of cotton, MA treated cotton and $\mathrm{ZnO}$ nanoparticles treated cotton. Spectra were collected at a resolution of $4 \mathrm{~cm}^{-1}$ and 32 scans.

\section{RESULTS AND DISCUSSION}

Fig. 1 shows SEM micrographs of $\mathrm{ZnO}$ nanoparticles treated cotton fabric with maleic acid in separate methods. The particles with the size of nano meter were related to $\mathrm{ZnO}$ nanoparticles.

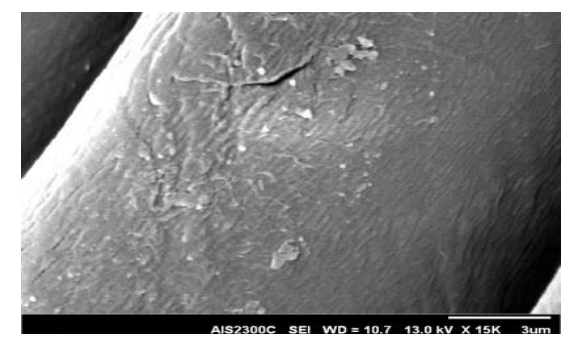

Fig. 1. SEM micrographs of treated fabrics with $\mathrm{ZnO}$ nanoparticles

Table 1 shows weight gain percentage, crease recovery angle and color yield of Maleic acid treated cotton fabric. By increasing the maleic acid concentration to $6 \%$, the weight gain and crease recovery angles of fabrics increased (Table 1).

Table 1. Weight gain, crease recovery angle and color yield of maleic acid treatment of cotton fabrics

\begin{tabular}{|c|c|c|c|}
\hline $\begin{array}{c}\text { Maleic } \\
\text { acid, \% }\end{array}$ & $\begin{array}{c}\text { Weight } \\
\text { gain, \% }\end{array}$ & $\begin{array}{c}\text { Crease Recovery } \\
\text { angle, degree }\end{array}$ & $\begin{array}{c}\text { Color yield, } \\
\mathrm{k} / \mathrm{s}\end{array}$ \\
\hline- & - & 260.2 & 12.54 \\
\hline 2 & 2.207 & 290.8 & 15.27 \\
\hline 4 & 3.125 & 316 & 15.36 \\
\hline 6 & 3.523 & 320.2 & 16.53 \\
\hline
\end{tabular}

Un-treated cotton had crease recovery angle of 260.2, by treatment of $6 \%$ maleic acid it reached to 320.2. As the maleic acid concentration increased, cross-linking of cellulose increased. Therefore, cross linking of cellulose caused more wrinkle resistant fabric. Methylene blue dye is a cationic dye which has a tendency to anionic surface, so that is able to absorb on the carboxylic groups of cotton. By maleic acid treatment of cotton fabric, carboxylic acid groups increase on cotton. In Table 1, color yield of stained cotton fabric, increased from 12.54 to 16.53 . The increase of color yield indicates the higher absorption of methylene blue dye, therefore higher carboxylic acid formation. Maleic acid can reach to higher wrinkle resistance of cotton fabric, and cause a single ester bond to cellulose, and disable to form the second cyclic anhydride intermediate for cross-linking of cellulose. Sodium hypophosphite and two MA esterify with cellulose and cross-linking of two celluloses happens [31]. The increase of fiber wrinkle resistance has dependency on $\mathrm{MA}$ and $\mathrm{NaH}_{2} \mathrm{PO}_{2}$ concentration. $\mathrm{H}-\mathrm{P}$ bond of $\mathrm{NaH}_{2} \mathrm{PO}_{2}$ adds to $\mathrm{C}=\mathrm{O}$ of $\mathrm{MA}$ to bond cotton by esterification and generating crosslink between two celluloses (Fig. 2).

After $\mathrm{ZnO}$ nanoparticles treatment, weight gain and crease recovery angle and color yield of treated fabrics were measured (Table 2). 
<smiles>CC(C)=CC=CC=CC=CC(=O)O</smiles>

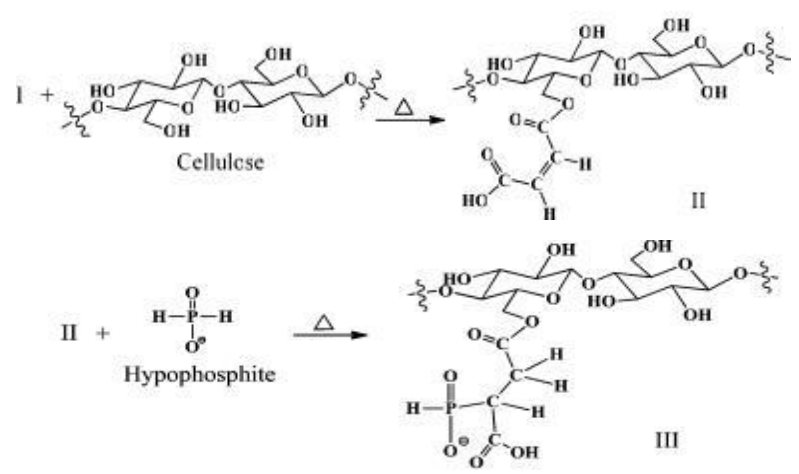

II + III $\stackrel{\Delta}{\longrightarrow}$

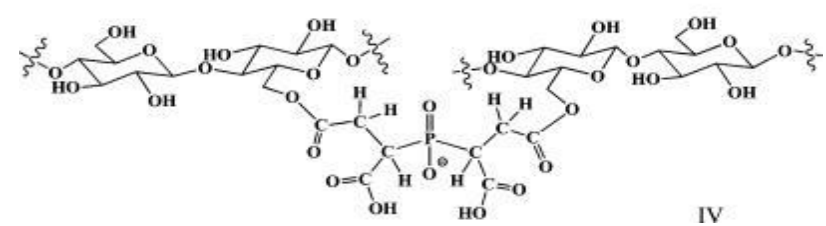

Fig. 2. Crosslinking of cellulose and maleic acid [2]

Table 2. Weight gain, crease recovery angle and color yield of $\mathrm{ZnO}$ nanoparticles treatment (Separate method:A), Simultaneous :B, MA: Maleic acid

\begin{tabular}{|c|c|c|c|c|c|c|}
\hline & A & B & A & B & A & B \\
\hline $\begin{array}{c}\text { MA, } \\
\%\end{array}$ & \multicolumn{2}{|c|}{$\begin{array}{c}\text { Weight gain, } \\
\%\end{array}$} & \multicolumn{2}{c|}{$\begin{array}{c}\text { Crease recovery } \\
\text { angle, degree }\end{array}$} & \multicolumn{2}{c|}{ Color yield } \\
\hline- & & & 218 & 218 & - & - \\
\hline 2 & 0.155 & 0.46 & 223.4 & 283.6 & 16.44 & 16.81 \\
\hline 4 & 0.291 & 0.643 & 252.6 & 314.6 & 17.38 & 18.34 \\
\hline 6 & 0.37 & 0.773 & 267.5 & 316.6 & 20.23 & 20.38 \\
\hline
\end{tabular}

By increasing maleic acid concentration form $2 \%$ to $6 \%$, Color yield of $\mathrm{ZnO}$ nanoparticles in two steps of treatment (Separate $\mathrm{ZnO}$ ) increased (Table 2). In simultaneously treatment, color yield reached to 20.38 . There was not any significant difference between two methods in color difference. It means that there was not any difference between two methods in absorption of methylene blue dye, therefore the same carboxylic acid groups' sites. Crease recovery angle of fabrics were increased by increasing concentration of maleic acid. In simultaneous treatment of $\mathrm{ZnO}$ nanoparticles with maleic acid, Crease recovery angle was higher than separate method (two steps method) of treatment. In separate method and second step of treatment, $\mathrm{ZnO}$ nanoparticles were treated at temperature of $180{ }^{\circ} \mathrm{C}$, this fixing temperature might be a reason for breaking the crosslinked cellulose-maleic acid bonding. The other possible reaction might be related to catalytic effect of metal oxide such as $\mathrm{ZnO}$ which act as a catalyst in reaction between maleic acid and cellulose that affected on cross-linking [32]. Weight gain of treated cotton with maleic acid and $\mathrm{ZnO}$ nanoparticles increased in simultaneous method (one step) as compared with separate method.

Table 3 shows color difference of $\mathrm{ZnO}$ nanoparticles treated cotton fabric after exposing to sunlight for selfcleaning effect. By increasing maleic acid concentration, color difference increased in separate method. In first step of the treatment of separate method, cross-linking of cellulose and MA happened, and then, by adding $\mathrm{ZnO}$ nanoparticles, $\mathrm{ZnO}$ nanoparticles penetrate into the fiber structure, more cross-linked sites, and more $\mathrm{ZnO}$ nanoparticles penetration.

Table 3. Color difference $(\Delta \mathrm{E})$ of $\mathrm{ZnO}$ nanoparticles treated cotton

\begin{tabular}{|c|c|c|c|c|}
\hline & $\begin{array}{c}\text { Separate } \\
\mathrm{ZnO}\end{array}$ & Simultaneous & $\begin{array}{c}\text { Separate } \\
\mathrm{ZnO}\end{array}$ & Simultaneous \\
\hline $\mathrm{MA}, \%$ & $30 \mathrm{~h}$ & $30 \mathrm{~h}$ & $60 \mathrm{~h}$ & $60 \mathrm{~h}$ \\
\hline 2 & 3.878 & 3.342 & 4.765 & 4.301 \\
\hline 4 & 4.519 & 3.637 & 5.504 & 4.384 \\
\hline 6 & 8.319 & 3.864 & 9.924 & 4.386 \\
\hline
\end{tabular}

The increase in $\mathrm{ZnO}$ nanoparticles penetration caused increase in $\Delta \mathrm{E}$ (color difference), therefore self-cleaning effect increased (Table 3 ). $\mathrm{ZnO}$ nanoparticles are capable of photo-degrading and self-cleaning of organic stain and dirt because of its photo catalytic performance. The selfcleaning happens by direct photo oxidation of the organic compounds in the presence of $\mathrm{H}^{+}$which leads to the decomposition of materials and removal from textiles. Exciting of $\mathrm{ZnO}$ leads to the formation of $\mathrm{e}^{-}$and $\mathrm{h}^{+}$. In the presence of water and oxygen, two photochemical reactions occur at the surface of $\mathrm{ZnO}$ : oxidation of $\mathrm{ZnO}$ that photo induced positive holes are involved and the other reaction is reduction which photo induced negative electrons are involved and the $\mathrm{HO}^{\circ}$ and $\mathrm{O}_{2}{ }^{\circ}$ were produced. Therefore, combination of the $\mathrm{HO}_{2}{ }^{\circ}$ leads to the formation of $\mathrm{H}_{2} \mathrm{O}_{2}$ (Fig. 3) [33,34]. In simultaneous treatment, by increasing MA concentration and cross-linked sites, there was a slight increase in color difference. It showed lower amount of $\mathrm{ZnO}$ nanoparticles absorption.

$\mathrm{ZnO}+\mathrm{h} v \rightarrow \mathrm{e}^{-}+\mathrm{h}^{+}$

$\mathrm{H}_{2} \mathrm{O}+\mathrm{h}^{+} \rightarrow \mathrm{H}^{+}+\mathrm{HO}$

$\mathrm{O}_{2}+\mathrm{e}^{-} \rightarrow \mathrm{O}_{2}{ }^{-}$

$\mathrm{O}_{2}{ }^{\circ}+\mathrm{H}^{+} \rightarrow \mathrm{HO}_{2}{ }^{\circ}$

$\mathrm{HO}_{2}{ }^{\circ}+\mathrm{e}^{-} \rightarrow \mathrm{HO}_{2}^{-}$

$\mathrm{HO}_{2}^{-}+\mathrm{H}^{+} \rightarrow \mathrm{H}_{2} \mathrm{O}_{2}$

Fig. 3. Scheme of antibacterial and sel-cleaning mechanism of $\mathrm{ZnO}[30]$

Fig. 4 shows zinc ion content on $\mathrm{ZnO}$ nanoparticles treated cotton fabrics which obtained from atomic absorption analysis.

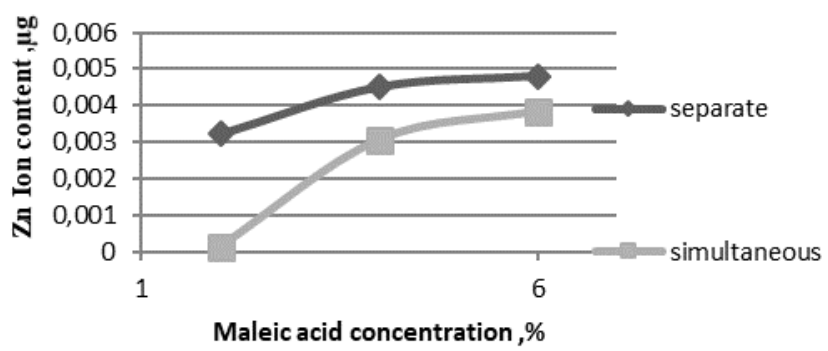

Fig. 4. $\mathrm{Zn}$ ion content per 100 grams of cotton fabric (in terms of $\mu$ grams) 
By increasing maleic acid concentration, the zinc ion content increased. In comparison between separate and simultaneous method, separate method showed higher $\mathrm{Zn}$ ion content. It means that in separate method of $\mathrm{ZnO}$ nanoparticles loading on wrinkle resistant cotton, higher amount of $\mathrm{ZnO}$ nanoparticles were absorbed. In simultaneous reaction of $\mathrm{ZnO}$ and Maleic acid with cotton fiber, the possible dominate reaction is related to maleic acid bonding with cellulose, then absorption of $\mathrm{ZnO}$ nanoparticles happens on cross-linked cellulose. $\mathrm{ZnO}$ nanoparticles and Maleic acid can be absorbed by hydroxyl groups of cellulose.

Fig. 5 shows bacteria reduction percentage of $\mathrm{ZnO}$ nanoparticles treatment of maleic acid treated cotton fabrics. The higher amount of antibacterial performance was related to separate method of treatment. In separate method of treatment, maleic acid treatment caused crosslinked sites, then $\mathrm{ZnO}$ nanoparticles were added to treated cotton. The antibacterial effect of $\mathrm{ZnO}$ nanoparticles is because of very reactive species of superoxide, hydrogen peroxide and hydroxyl that acts on the surface of $\mathrm{ZnO}$ after exposing to UV and light. The possible reaction according to researches is the formation of $\mathrm{H}_{2} \mathrm{O}_{2}$ on the surface of the $\mathrm{ZnO}$ which inhibits growth of bacteria. The formation of $\mathrm{H}_{2} \mathrm{O}_{2}$ is according to Fig. 3 [34]. These results were agreement with self-cleaning results (Table 3) which separate method indicated higher color difference. The atomic absorption analysis also indicated the same results (Fig. 4) and the separate method showed higher $\mathrm{Zn}$ ion content, therefore higher $\mathrm{ZnO}$ nanoparticles.

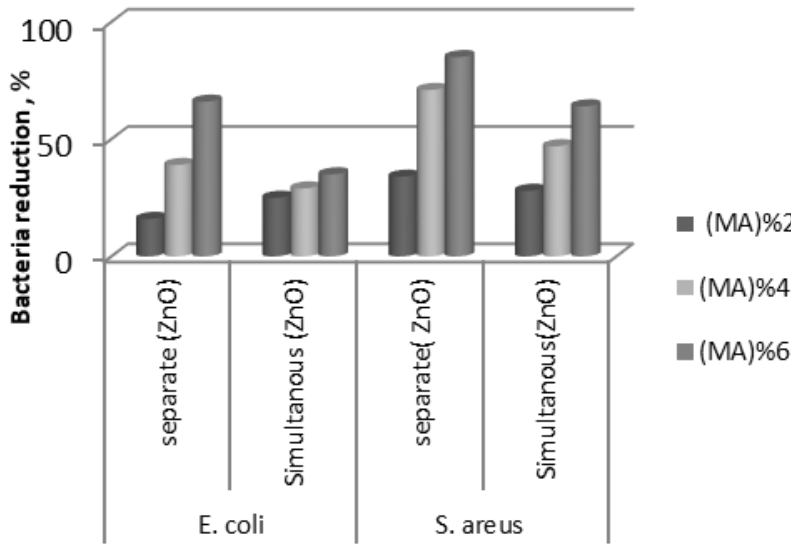

Fig. 5. Bacteria reduction percentage of $\mathrm{ZnO}$ nanoparticles treatment on maleic acid treated cotton

Fig. 6 a shows the FTIR/ATR spectra of un-treated cotton and treated cotton with maleic acid. It can be seen that the band at $1644 \mathrm{~cm}^{-1}$ is due to the bending mode of the hydrogen-bonded hydroxyl group of cellulose [31], and for maleic acid treated cotton, band at $1740 \mathrm{~cm}^{-1}$ is due to the carbonyl bands carboxyl and ester [2], which was formed between MA and cotton at curing. Fig. $4 \mathrm{~b}$ indicates FTIR/ATR spectra of cotton, treated cotton with maleic acid (cotton+MA), maleic acid treated cotton with $\mathrm{ZnO}$ in one step (simultaneous) and two steps (separate ) methods. The band at $3371 \mathrm{~cm}^{-1}$ is related to hydroxyl groups of cellulose [35]. The intensity of peak at $3371 \mathrm{~cm}^{-1}$ for separate method increased as compared with simultaneous method. The higher intensity might be related to the higher banding between $\mathrm{ZnO}$ and cellulose or higher absorption of $\mathrm{ZnO}$ nanoparticles. The peak at $530 \mathrm{~nm}$ is due to the $\mathrm{ZnO}$ nano aprticles $[31,35]$.
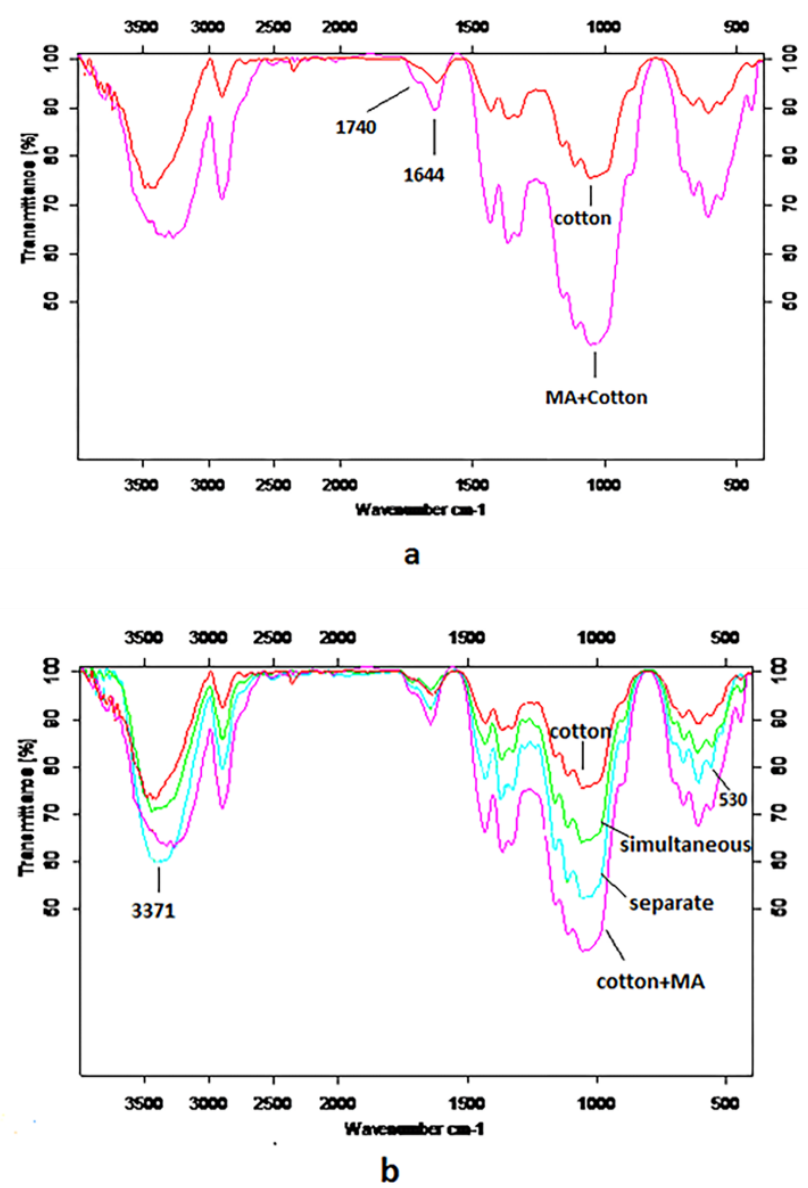

Fig. 6. FTIR/ATR spectra of cotton, Maleic acid treated cotton (Cotton+ MA): a-spectra of cotton, Cotton +MA , $\mathrm{ZnO}$ loading in simultaneous method; $b$-in separate method

\section{CONCLUSIONS}

The $\mathrm{ZnO}$ nanoparticles treatment of cotton fabric with maleic acid increased wrinkle resistance, weight gain and methyelene blue dye absorption. Color difference or selfcleaning effect of treated fabrics showed that by increasing maleic acid concentration, color difference increased in separate method. In simultaneous treatment, by increasing MA concentration and cross-linked sites, there was a slight increase in $\Delta \mathrm{E}$ and self-cleaning effect. Results indicated that $\mathrm{ZnO}$ nanoparticles amount in separate method was higher than simultaneous method. Antibacterial performance increased for separate method of $\mathrm{ZnO}$ nanoparticles treatment. Although, simultaneous methods of treatment can be useful in textile industry for reducing costs and duration of processing, the separate method is useful for self-cleaning and anti-bacterial performance of wrinkle resistant cotton fabric.

\section{REFERENCES}

1. Nourbakhsh, S., Habibi, S., Rahimzadeh, M. Copper Nano-particles for Antibacterial Properties of Wrinkle 
Resistant Cotton Fabric Materials Today: Proceedings 4 2017:pp. 7032-7037.

https://doi.org/10.1016/j.matpr.2017.07.034

2. Yang, C.Q., Chen, D., Guan, J., He, Q. Cross-Linking Cotton Cellulose by the Combination of Maleic Acid and Sodium Hypophosphite. 1. Fabric Wrinkle Resistance Industrial \& Engineering Chemistry Research 49 2010: pp: $8325-8332$.

https://doi.org/10.1021/ie1007294

3. Yang, C.Q. Infrared Spectroscopy Studies of Cyclic Anhydrides as Intermediates for Ester Crosslinking of Cotton Cellulose by Polycarboxylic Acids Journal of Applied Polymer Science 75 2000: pp. 327-336. https://doi.org/10.1002/(sici)1097-4628.

4. Yang, C.Q., Wu, X. Flame Retardant Finishing of Cotton Fleece Fabric. Part IV Bifunctional Carboxylic Acids Journal of Fire Sciences 27 2009: pp. 431-444. https://doi.org/10.1177/0734904109105511

5. Wu, X., Yang, C.Q., He, Q. Flame Retardant Finishing of Cotton Fleece. Part VII Polycarboxylic Acids with Different Numbers of Functional Group Cellulose 17 2010: pp. $859-870$.

https://doi.org/10.1007/s10570-010-9416-8.

6. Vivod, V., Yang, C.Q., Voncina, B. Non-formaldehyde Polyfunctional Cross-linking System for Cotton Advanced Materials Research 441 2012: pp. 5-9.

https://doi.org/10.4028/www.scientific.net/AMR.441.5

7. Mittal, K.L., Bahners, T. Textile finishing: Recent developments and future trends, Wiley, Usa, 2017: pp. 86.

8. Cheng, X., Yang, C.Q. Flame Retardant Finishing of Cotton Fleece Fabric: Part V. Phosphorus Containing Maleic Acid Oligomers Fire Materials 33 2009: pp. 365-375. https://doi.org/10.1002/fam.1008.

9. Yang, C.Q., He, Q., Voncina, B. Cross-linking Cotton Cellulose by the Combination of Maleic Acid and Sodium Hypophosphite. 2. Fabric Fire Performance Industrial \& Engineering Chemistry Research 50 2011: pp. $5889-5897$.

https://doi.org/10.1021/ie1007294.

10. Behnajady, M.A., Modirshahla, N., Hamzavi, R. Kinetic Study on Photocatalytic Degradation of C.I. Acid Yellow 23 by $\mathrm{ZnO}$ Photocatalyst Journal of Hazardous Materials 133 2006: pp. 226-232. https://doi.org/10.1016/j.jhazmat.2005.10.022.

11. Vigneshwaran, N., Kumar, S., Kathe, A.A, Varadarajan, P.V., Prasad, V. Functional Finishing of Cotton Fabrics Using Zinc Oxide-soluble Starch Nanocomposites Nanotechnology 17 2006: pp. $5087-5095$.

https://doi.org/10.1088/0957-4484/17/20/008

12. Becheri, A., Durr, M., Nostro, PL., Baglioni, P. Synthesis and Characterization of Zinc Oxide Nanoparticles: Application to Textiles as UV-absorbers Journal of Nanoparticle Research 10 2007: pp. 679-689. https://doi.org/10.1007/s11051-007-9318-3

13. Xu, T., Xie, C.S. Tetrapod-like Nano-particle $\mathrm{ZnO} /$ acrylic Resin Composite and its Multi-function Property Progress in Organic Coatings 46 2003: pp. 297-301. https://doi.org/10.1016/S0300-9440(03)00016-X

14. Cao, Z., Zhang, Z., Wang, F., Wang, G. Synthesis and UV Shielding Properties of Zinc oxide Ultrafine Particles Modified with Silica and Trimethylsiloxane Colloids and Surfaces A: Physicochemical and Engineering Aspects 340 (1-3) 2009: pp. 161-167.

https://doi.org/10.1016/j.colsurfa.2009.03.024
15. Kwak, G., Jung, S., Yong, K. Multi-functional Transparent ZnO Nanorod Films Journal of Nanotechnology 22 (11) 2011: pp. 1-7. https://doi.org/10.1088/0957-4484/22/11/115705

16. Rajagopalan, N., Khanna, A.S. Effect of Size and Morphology, on UV-blocking Property of Nano $\mathrm{ZnO}$ in Epoxy Coating International Journal of Scientific and Research Publications 3 (4) 2013: pp. 1-14. https://doi.org/10.29322/ijsrp-p16114

17. Padmavathy, N., Vijayaraghavan, R. Enhanced Bioactivity of ZnO Nano particles: an Antimicrobial Study Science and Technology of Advanced Materials 9 2008: pp. $1-7$. https://doi.org/10.1088/1468-6996/9/3/035004

18. Fortuny, A., Bengoa, C., Font, J., Fabregat, A. Bimetallic Catalysts for Continuous Catalytic Wet Air Oxidation of Phenol Journal of Hazardous Materials B 64 1999: pp. $181-193$. https://doi.org/10.1016/s0304-3894(98)00245-3

19. Rana, S., Rawat, J., Sorensson, M.M., Misra, R.D.K. Antimicrobial Function of Nd3+-doped Anatase TitaniaCoated Nickel Ferrite Composite Nanoparticles: A Biomaterial System Acta Biomaterialia 2 2006: pp. $421-432$. https://doi.org/10.1016/j.actbio.2006.03.005.

20. Sawai, J., Yoshikawa, T.J. Quantative Evalution of Antifungal Activity of Metallic Oxide Powders ( $\mathrm{MgO}, \mathrm{CaO}$ and $\mathrm{ZnO}$ ) by an Indirect Conductimetric Assay Journal of Applied Microbiology 96 2004: pp. 803-809. https://doi.org/10.1111/j.1365-2672.2004.02234.x

21. AbdElhady, M.M. Preparation and Characterization of Chitosan/Zinc Oxide Nanoparticles for Imparting Antimicrobial and UV Protection to Cotton Fabric International Journal of Carbohydrate Chemistry 2012: pp. 1-6. https://doi.org/10.1155/2012/840591.

22. Zohdy, M.H., Abdel Kareem, H., El-Naggar, A.M., Hassan, M.S. Microbial Detection, Surface Morphology, and Thermal Stability of Cotton and Cotton/Polyester Fabrics Treated with Antimicrobial Formulations by a Radiation Method Journal of Applied Polymer Science 89 2003: pp. 2604-2610.

https://doi.org/10.1002/app.12472

23. Rajendran, R., Balakumar, C., Mohammed Ahammed, H.A, Jayakumar, S., Vaideki, K., Rajesh, E.M. Use of Zinc Oxide Nanoparticles for Production of Antimicrobial Textiles International Journal of Engineering, Science and Technology 2(1) 2010: pp. $202-208$. https://doi.org/10.4314/ijest.v2i1.59113

24. Li, Q., Chen, S., Jiang, W. Durability of Nano ZnO Antibacterial Cotton Fabric to Sweat Journal of Applied Polymer Science 103 2007: pp. 412-416. https://doi.org/10.1002/app.24866.

25. Singh, G., Joyce, E.M., Beddow, J., Mason, T.J. Evaluation of Antibacterial Activity of ZnO Nanoparticles Coated Sono-chemically onto Textile Fabrics Journal of Microbiology, Biotechnology and Food Sciences 2 (1) 2012: pp. $106-120$.

26. El-Naggar, A.M., Z Zohdy, M.H., Hassan, M.S., Khalil, E.M. Antimicrobial Protection of Cotton and Cotton/Polyester Fabrics by Radiation and Thermal Treatments: I. Effect of $\mathrm{ZnO}$ Formulation on the Mechanical and Dyeing Properties Journal of Applied Polymer Science 88 2003: pp. $1129-1137$. 
https://doi.org/10.1002/app.11722

27. Instrumental Color Measurement, Evaluation Procedure 6, Technical Manual of the American Association of Textiles Chemists and Colorist, NC, USA, 2010: pp. 374-379.

28. ASTM D3776, Standard Test Method for Mass per Unit Area (weight) of Fabric, Annual Book of ASTM Standards, Section 7, Textiles.

29. Assessment of Antibacterial Finishes on Textile Materials, AATCC Test Method 100-2004, Technical Manual of the American Association of Textiles Chemists and Colorist, NC, USA, 2010: pp. 142-144.

30. Instrumental Assessment of the Change in Color of a Test Specimen, Evaluation Procedure 7, Technical Manual of the American Association of Textiles Chemists and Colorist, NC, USA, 2010: pp. 380-381.

31. Peng, H., Yang, C.Q., Wang, S. Non-formaldehyde Durable Press Finishing of Cotton Fabrics Using the Combination of Maleic Acid and Sodium Hypophosphite $\begin{array}{ll}\text { Carbohydrate Polymers } 87 & \text { 2012: pp. 491-499. }\end{array}$ https://doi.org/10.1016/j.carbpol.2011.08.013

32. Hosseini-Sarvari, M. Catalytic Organic Reactions on $\mathrm{ZnO}$ Current Organic Synthesis 10 (5) 2013: pp. 697-723. https://doi.org/10.2174/1570179411310050003

33. Verbic, A., Gorjanc, M., Simoncic, B. Zinc Oxide for Functional Textile Coatings: Recent Advances Coating 9 2019: pp. $1-26$

https://doi.org/10.3390/coatings9090550

34. Zhao, S.W., Guo, C.R., Hu, Y.Z., Guo, Y.R., Pan, Q.J. The Preparation and Antibacterial Activity of Cellulose/ZnO Composite: A Review Open Chemistry 16 2018: pp. $9-20$. https://doi.org/10.1515/chem-2018-0006

35. Lefatshe, K., Muiva, C.M., Kebaabetswe, L.P. Extraction of Nano Cellulose and in situ Casting of $\mathrm{ZnO} /$ Cellulose Nano Composite with Enhanced Photo Catalytic and Antibacterial Activity Carbohydrate Polymers 164 2017: pp. $301-308$. https://doi.org/10.1016/J.carbpol.2017.02.020

(C) Nourbakhsh et al. 2021 Open Access This article is distributed under the terms of the Creative Commons Attribution 4.0 International License (http://creativecommons.org/licenses/by/4.0/), which permits unrestricted use, distribution, and reproduction in any medium, provided you give appropriate credit to the original author(s) and the source, provide a link to the Creative Commons license, and indicate if changes were made. 